\title{
Storm Surge: Physical Processes and an Impact Scale
}

\author{
Hal Needham and Barry D. Keim \\ Department of Geography and Anthropology Louisiana State University \\ U.S.A.
}

\section{Introduction}

Tropical cyclone-generated storm surges create natural disasters that are among the most deadly and costly global catastrophes. Individual disasters have inflicted hundreds of thousands of fatalities and billions of dollars in damage. In 1970, a tropical cyclone in the Bay of Bengal generated a 9.1-meter surge which killed approximately 300,000 people in Bangladesh (Frank and Husain 1971; Dube et al. 1997; De et al. 2005). More recently, and well into the age of satellite meteorology, a storm surge in 1991 killed approximately 140,000 people in Bangladesh (Dube et al. 1997). Although the magnitude of storm surge heights and loss of life are highest along the shores of Bangladesh and India, such disasters are not limited to countries with developing economies. The 1900 Galveston Hurricane generated a 6.1-meter surge (Garriott 1900), which killed between 6,000 and 8,000 people in Galveston, Texas (Rappaport and Fernandez-Partagas 1995), producing the most deadly natural disaster in United States history (National Oceanic and Atmospheric Administration 1999). More recently, Hurricane Katrina (2005) generated an 8.47-meter surge (Knabb et al. 2006), which claimed more than 1,800 lives along the coasts of Louisiana and Mississippi, and inflicted $\$ 81$ billion dollars in damage (McTaggart-Cowan et al. 2008).

While tropical cyclone-generated storm surge is a deadly and costly hazard, it is also scientifically complex, because meteorological, oceanographic and geographic factors influence the height, extent and duration of storm surge flooding. Such factors include maximum sustained hurricane wind speed at landfall and offshore, hurricane size, hurricane forward speed, the angle of hurricane approach to the coastline, bathymetry of coastal waters, coastline shape and the presence of barriers or obstructions to surge waters on land. Although relationships between some of these factors and resultant surge heights may seem intuitive (e.g. the assumption that stronger hurricanes always generate higher surges), storm surge observations reveal that a combination of physical factors influence surge characteristics. As a result, weaker hurricanes sometimes generate higher surges than stronger hurricanes. For example, Hurricane Ike (2008) generated a 5.33-meter surge along the Upper Texas Coast, although maximum sustained winds at landfall were only $175 \mathrm{~km} /$ hour (Berg 2009), whereas Hurricane Charley in Western Florida had maximum sustained winds of $240 \mathrm{~km}$ / hour at landfall, but only generated a 2.13-meter surge, partly because the storm rapidly intensified just before making landfall (Pasch et al. 2004).

The complex nature of storm surge makes this phenomenon difficult to forecast and difficult for coastal populations to understand. In cases where storm surge heights and extents are 
accurately forecast, coastal populations still commonly misunderstand storm surge impacts on coastal buildings, marine infrastructure, utilities, and transportation infrastructure, such as coastal roads and bridges. This chapter addresses these issues by discussing the physical processes that generate storm surges, while providing some insight into impacts in lowlying coastal communities along the United States' Gulf of Mexico Coast. Such information is likely helpful to professionals in the fields of emergency management and law enforcement, planning, insurance, construction, urban planning, health care, science and engineering, as well as to coastal populations who live in regions vulnerable to tropical cyclone-generated storm surges.

\section{Physical processes that generate storm surge}

A storm surge is defined as a dome of increased sea level height in association with the approach of an intense cyclone. Persistent onshore winds, in conjunction with reduced air pressure, force water levels to rise, especially in shallow water of impacted coasts. Although tropical or extratropical cyclones can theoretically produce storm surges in any ocean basin, tropical cyclones produce the most destructive surges in terms of extreme water-level heights and human impacts.

An understanding of tropical cyclone-generated storm surge climatology requires a brief examination of the physical processes that shape tropical cyclone development. These parameters include sea surface temperatures exceeding 26 degrees C (Ali 1996; Holland 1997; Gray 1998), and proximity to the Intertropical Convergence Zone (ITCZ), or its regional manifestation, such as the South Pacific Convergence Zone (SPCZ) (De Scally 2008). Proximity to this global band of low pressure is necessary to provide the atmospheric lift for cyclonic development (Ali 1996; Dube et al. 1997; De Scally 2008). Furthermore, tropical cyclones tend to form between $5^{\circ}-25^{\circ}$ of latitude because at these latitudes the Coriolis parameter is sufficient to generate the dynamic potential of an area of convection (Gray 1998). As the Coriolis parameter is a function of latitude, with no Coriolis forcing at the equator and higher forcing found at higher latitudes, tropical cyclone development is generally suppressed near the Equator (Gray 1975). Although the Coriolis parameter is more favorable for cyclonic development in higher latitudes where forcing is greatest, cooler ocean waters and detachment from the ITCZ in latitudes poleward of approximately 25 degrees latitude suppress the development of tropical cyclones. Figure 1 and Table 1 reveal the most favorable regions for tropical cyclogenesis, and the average annual number of tropical cyclones observed in each ocean basin (Landsea 2007).

Once a tropical cyclone has developed, atmospheric circulation will usually steer the cyclone from the point of origin, sometimes transporting the disturbance thousands of kilometers from the point of origin. The atmospheric circulation of the specific ocean basin will govern the exact path of the storm. Typical circulation patterns exist for each basin, depending on several physical factors. For example, the clockwise circulation around the Bermuda and Hawaiian Highs, the dominant mid-oceanic features in the North Atlantic and North Pacific Oceans, respectively, typically produce easterly trade winds between 10 and 25 degrees latitude, the region of highest tropical cyclogenesis. This typical circulation pattern causes most tropical cyclones in these basins to initially travel westward in the easterly trade winds, before making a northerly turn as they approach North America or East Asia. Figure 2 depicts this pattern with the 270 August tropical cyclone tracks that took place in the north Atlantic from 1886 - 2006. 
Spatial patterns of tropical cyclone landfalls develop as the processes of tropical cyclone development and movement are considered within the context of physical geography. Exposed islands, peninsulas and capes often experience the highest landfall frequencies. Coasts that curve in a convex manner, such as the North Carolina coast, along the eastern seaboard of the United States, protrude from the continent and experience higher frequencies of tropical cyclone strikes than concave-bending coasts, such as the Georgia coast, 650 kilometers to the southwest (Keim et al. 2007).

As tropical cyclones approach a coastline, several additional factors determine the characteristics of the resultant storm surges. These factors include maximum sustained cyclonic winds at landfall and offshore, minimum central pressure, cyclone size, forward movement and angle of approach to the coast, shape and bathymetry of the coastline, and presence of obstructions to flowing water.
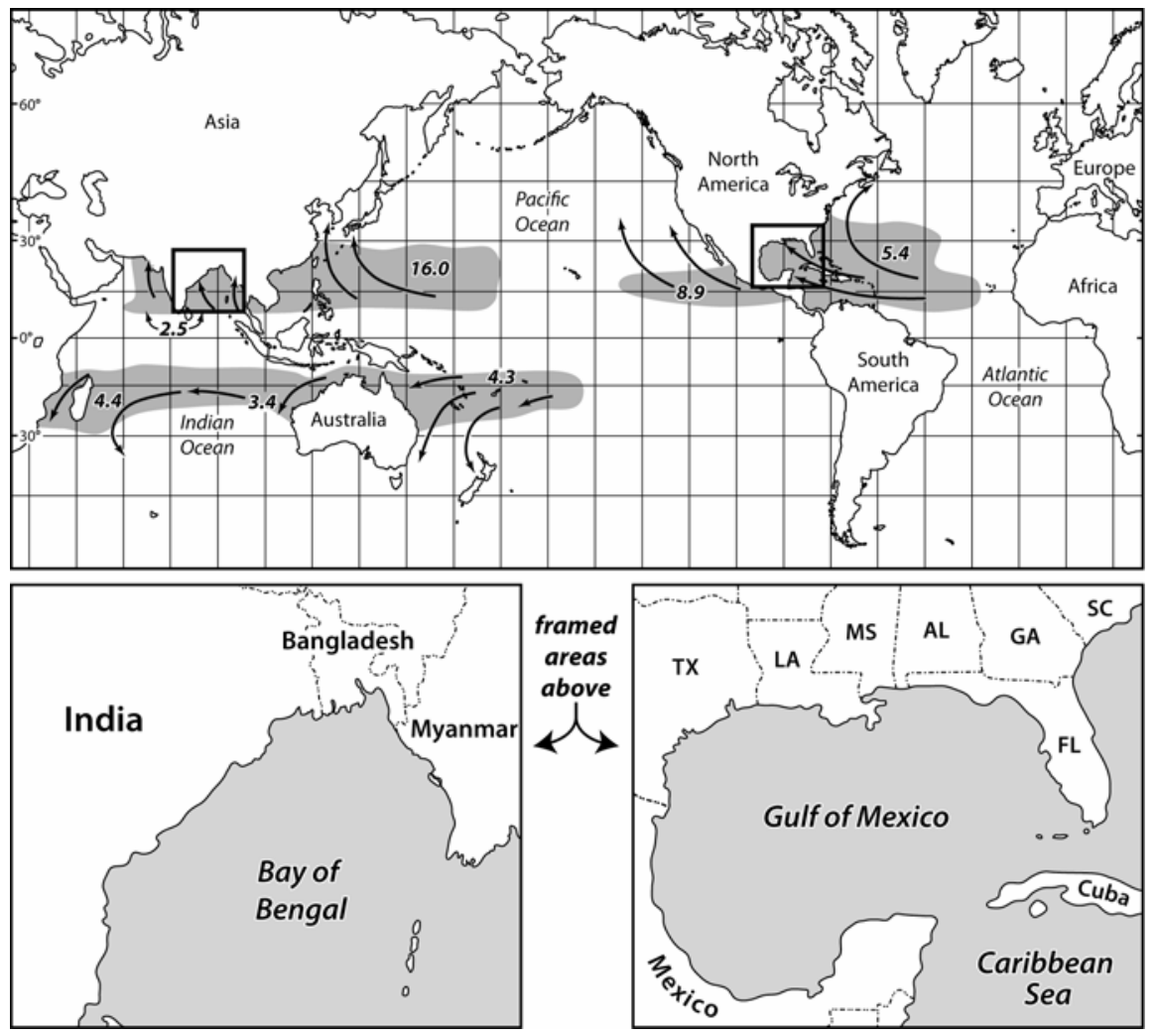

Fig. 1. Regions of global tropical cyclogenesis, and the average annual number of hurricanestrength systems per basin.

Wind stress is the predominant factor forcing storm surge and destructive waves generated by hurricanes (Harris 1963). A quantitative relationship exists between wind speed and water heights, as wind stress exerts a force on water that increases exponentially as wind speeds increase (Ali 1996). Kurian et al. (2009) state that wind stress accounts for $80-85 \%$ of 
Tropical storm or stronger (sustained winds greater than 17 $\mathrm{m} / \mathrm{s}$ )

Basin

Atlantic Average

9.7

NE Pacific

NW Pacific

$\mathrm{N}$ Indian

SW Indian

Aus SE Indian

Aus SW Pacific

Globally
Percentage

11.6

19.7

30.7

6.5

12.4

8.2

10.8

100
Hurricane/ Typhoon

(sustained winds greater than 33

$\mathrm{m} / \mathrm{s}$ )

Average

Percentage

5.4

12.0

8.9

19.8

16.0

35.6

2.5

5.6

4.4

9.8

3.4

7.6

4.3

9.6

44.9

100

Table 1. Average annual number of tropical cyclones that develop in selected ocean basins, from Landsea (2007).

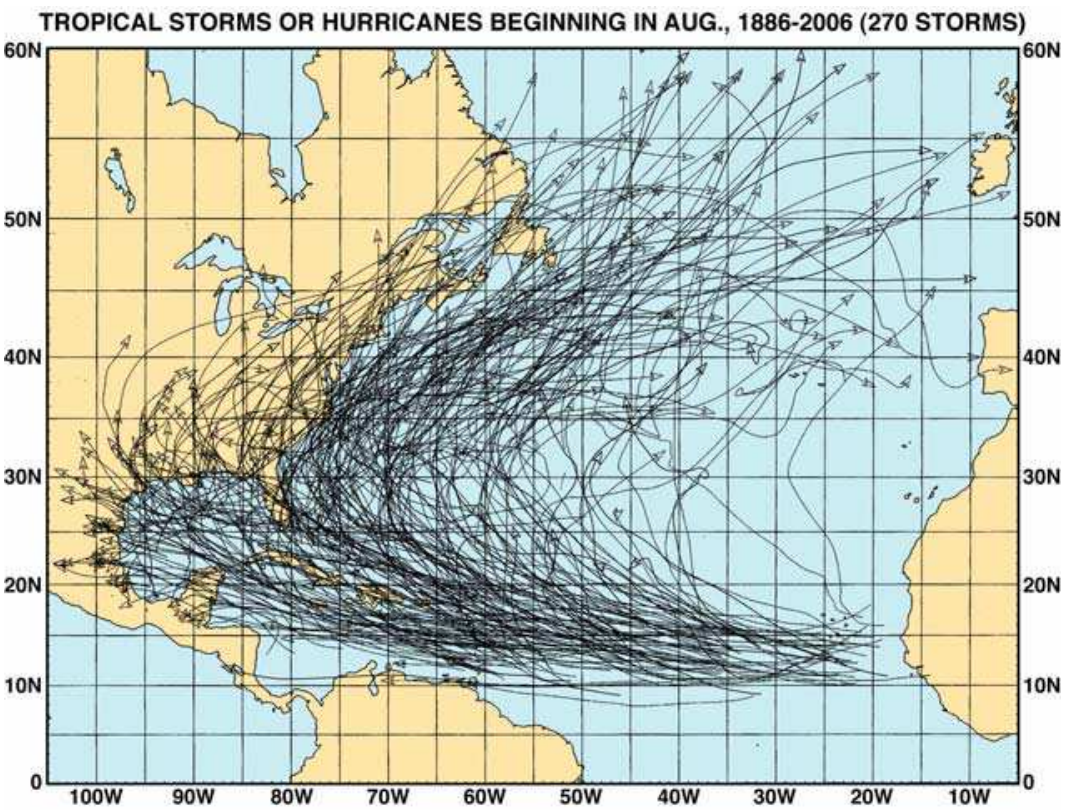

Fig. 2. August tracks of North Atlantic Basin hurricanes, 1886-2006, from Keim and Muller (2008), adapted from Neumann et al. (1993).

the generated surge, however, as recent research has discovered the importance of other cyclonic variables on storm surge heights, some scientists may argue that these figures provided by Kurian et al. (2009) overestimate the influence of wind speed.

It should be noted that pre-landfall wind speeds likely influence maximum storm surge heights to a greater extent than wind speeds at landfall, especially for hurricanes that 
rapidly strengthen or weaken as they approach the coast. Jordan and Clayson (2008) discovered that a scaled 24-hour, pre-landfall intensity average and a 12-hour pre-landfall instantaneous wind speed seem to be the best predictors of storm surge height. This may seem counterintuitive, as many meteorologists, as well as the media, focus attention on predicted wind speeds at landfall. However, the transfer of momentum from the atmosphere to the water, as strong winds blow over the water surface, requires time, therefore enabling hurricanes that rapidly weaken (strengthen) as they approach the coast to often generate higher (lower) surges than anticipated. Hurricanes Katrina and Wilma (2005) exemplify this phenomenon. The National Hurricane Center downgraded Katrina's surge forecast as the storm rapidly weakened while approaching the Mississippi Coast, but upgraded Hurricane Wilma's surge forecast as the hurricane rapidly intensified before making landfall in Southwest Florida. In hindsight, both of these changes increased forecasting errors, as the surge levels predicted using offshore intensities were more accurate than the forecasts that accounted for sudden intensity changes before landfall (Jordan and Clayson 2008).

An inverse relationship exists between air pressure and storm surge heights. This relationship is sometimes called the inverted barometer effect, or law of the inverted barometer (Welander 1961). As barometers measure the amount of atmospheric pressure exerting downward force on a given location at Earth's surface, reduced barometric readings mean less atmosphere is pressing down from above, thus, enabling sea levels to rise slightly. The sea level rises approximately one centimeter for every millibar of air pressure reduction (Welander 1961). This indicates that differences in air pressure account for a relatively small component of storm surge rise. For example, consider Hurricane Camille, an unusually intense hurricane that struck the Mississippi Coast in the United States Gulf of Mexico in 1969, produced one of the lowest air pressure observations ever recorded in the United States. The minimum central pressure in this hurricane was 905 millibars (Simpson et al. 1970), or approximately 108 millibars less than the atmospheric average pressure of 1013 millibars (National Aeronautics and Space Administration 2010). The inverted barometer effect indicates that reduced air pressure in this cyclone accounted for only 1.08 meters in storm surge rise, or about 14 percent of the maximum storm surge height of 7.5 meters at Pass Christian, Mississippi (Simpson et al. 1970).

Cyclone size is an important factor that has been underestimated until recently, after very large hurricanes Katrina (2005) and Ike (2008) generated larger surges than anticipated (Irish et al. 2008). The relationship between storm size and surge levels has likely been underestimated because research conducted on storms from the 1950s through 1970s lacked examples of massive storms like Katrina (Irish et al. 2008). Hurricane Katrina's size likely enabled the storm, a category-3 storm on the Saffir-Simpson Scale at landfall, to generate larger surge heights than category-5 Camille along the same coastline. Katrina's Category-5 winds, one day before landfall, enabled the storm to generate such a massive surge. It is believed that the massive size of Katrina then enabled it to maintain this enormous surge even as it weakened before striking the coastline. As such, both Hurricanes Charley (2004) and Katrina (2005) also indicate that the lifecycle of hurricanes before landfall can play some role in producing surge. For example, Hurricane Charley's rapid intensification before landfall did not allow for a large build-up of surge over time like Hurricane Katrina, which weakened before landfall. 


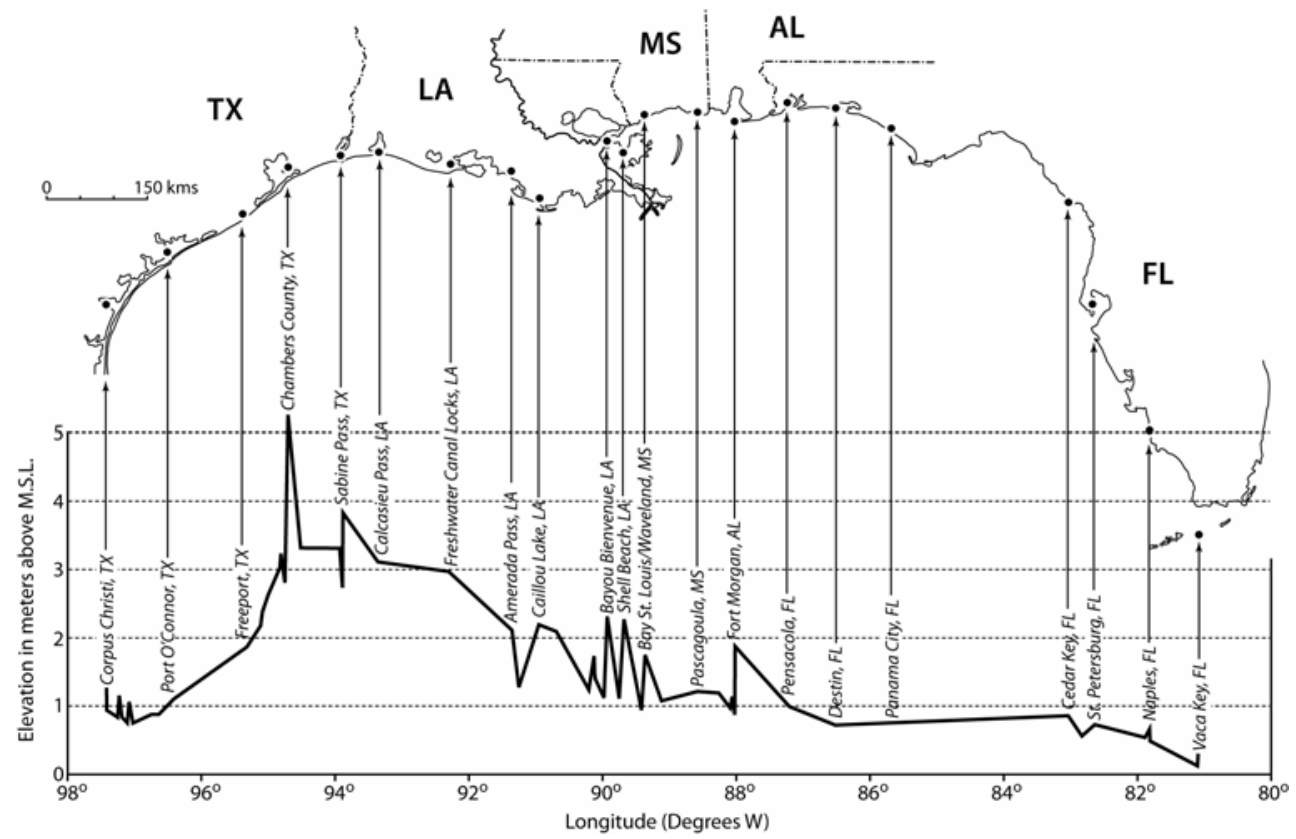

Fig. 3. High water profile for Hurricane Ike in the Gulf of Mexico, created from selected storm surge observations provided by Berg (2009).

In addition to producing higher surges, larger cyclones also inundate more coastline. In a modeling experiment, Irish et al. (2009) discovered that a $10 \mathrm{~km}$ increase in the hurricane pressure radius, a measure of hurricane size, produced a $20-100 \%$ increase in the extent of coastline inundated by high surge, at least 2 meters high in this particular experiment. This reasoning partially explains the reason why Hurricane Ike (2008) inundated more than 350 $\mathrm{km}$ of Texas and Louisiana Coastline with at least 2 meters of storm surge (See Figure 3).

Forward cyclonic movement is a factor often overlooked in surge research (Rego and Li 2009). Weisberg and Zheng (2006) resolved that slower-moving cyclones generate higher surges than faster-moving cyclones, because slower-moving storms have more time to redistribute water. It is also reasonable that slower-moving storms would elevate water levels for longer time periods, therefore, increasing the amount of time that coastal communities are susceptible to damage from surge and waves.

Coastline shape and the presence of natural and artificial obstructions to flowing water, such as coastal forests and levees, have profound effects on storm surge, sometimes producing extreme localized water level differences (Jarvinen and Neumann 2005). The highest surges usually occur where water approaches the coast in a perpendicular direction, especially when funneled into inlets and bays. The Advanced CIRCulation Model for Coastal Open Hydrodynamics (ADCIRC) of Hurricane Katrina's surge clearly depicts these localized differences along the Mississippi River south of New Orleans (Interagency Performance Evaluation Taskforce Report 2006). Both natural and artificial levees along the river inhibited surge from flowing across the river from east to west, therefore enhancing surge levels on the east side of the river. In some locations surge levels on the east side of the river were more than three meters higher than the west side, less than two kilometers away 
(Figure 4). Storm surge levels were also enhanced along the Mississippi River Gulf Outlet Reach 2 (MRGO Reach 2), as strong winds blew from the northeast, nearly perpendicular to the levees in this section (Ebersole et al. 2010).

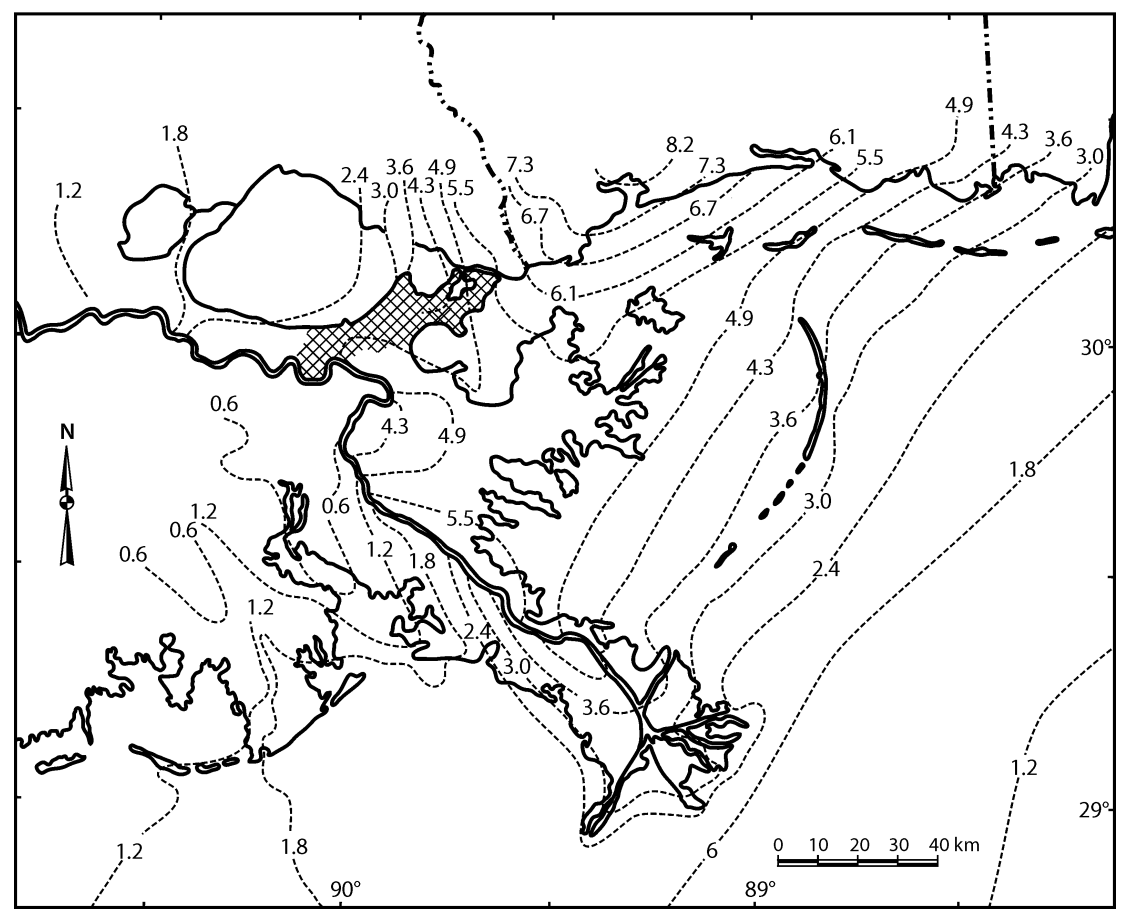

Fig. 4. The Advanced CIRCulation Model for Coastal Open Hydrodynamics (ADCIRC) map of maximum storm surge generated by Hurricane Katrina along the Louisiana and Mississippi coasts in the Gulf of Mexico. Original source is Interagency Performance Evaluation Taskforce (IPET) Report, 2006, although this graphic is adapted from Keim and Muller (2009).

Notes: 1. Water levels in this figure are given in meters above NAVD88. 2. The ADCIRC surge model reveals dramatic localized difference in storm surge along the Mississippi River levee, south of New Orleans. Surge levels on the east side of the river are more than 3 meters higher than the west side of the river in some locations.

Shallow bathymetry enhances storm surge because deeper water currents cannot carry away excess water, and as a result, water accumulates in shallow areas (Rappaport and Fernandez-Partagas 1995). Bays and gulfs, especially associated with large river deltas, therefore, generally experience larger surges than shorelines adjacent to open ocean or steeper continental shelves. For example, the extremely shallow waters near the mouth of the Mississippi River, created by extensive silt deposits, enhance the surge levels of hurricanes that track near the delta. These shallow waters enhanced the surge heights of Hurricanes Camille (1969) and Katrina (2005), helping these cyclones generate the two largest storm surges in United States history. Pass Christian, Mississippi, on the eastern shore of Bay St. Louis, observed the location of peak storm surge in both of these events. 
Chen et al. (2008) hypothesize that the shallow waters south of the Mississippi Coast, produced by deltaic lobes from the Mississippi River, were the primary reason that Hurricane Katrina's surge was extraordinarily high, and that the surge may have been four meters lower had Katrina tracked over a wider and more steeply sloping continental shelf, similar to the bathymetry south of Mobile Bay, Alabama (Figure 5).

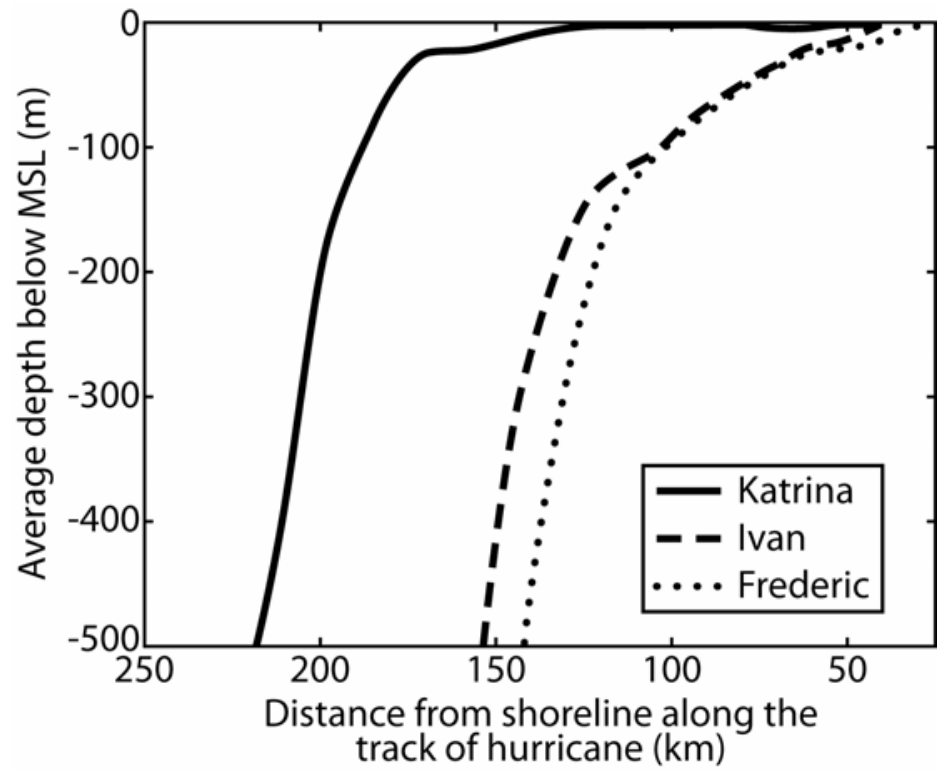

Fig. 5. Average bathymetry, or water depth, located $90 \mathrm{~km}$ east of the tracks of Hurricanes Katrina, Ivan and Frederic in the Gulf of Mexico. The bottom profiles indicate that the onshore winds of Hurricane Katrina blew over much shallower water than Ivan and Frederic, as the storm approached shore. From Chen et al. (2008).

Storm surges sometimes inundate entire regions; widespread surge events can flood more than 1,000 kilometers of coastline (Berg 2009). Larger cyclones generally inundate more extensive areas than smaller cyclones with similar maximum wind velocities, while cyclones that track parallel or at an oblique angle to the coastline will usually flood longer stretches of shoreline than cyclones that make a perpendicular approach to the coast at landfall. The high water profiles depicted in Figures 3 and 7 reveal that Hurricane Ike inundated a much larger expanse of coastline than Hurricane Camille, even though Hurricane Ike made landfall as a Category-2 storm on the Saffir Simpson Scale, compared with Camille's extraordinary Category-5 sustained winds and 190-mile-per-hour gusts (National Weather Bureau 1969) along the Mississippi coast. Ike's much larger geographic size and oblique path relative to the coastline enabled the cyclone to inundate a wider swath of the coast.

Generally, the portion of coastline that observes onshore winds will usually experience the greatest surge levels, with water heights increasing closer to the path of the cyclone. In contrast, the region that observes offshore winds will often experience much lower surge levels. In the northern hemisphere, onshore winds are observed to the right of the path of the cyclone, while offshore winds are experienced to the left (Figure 6). 


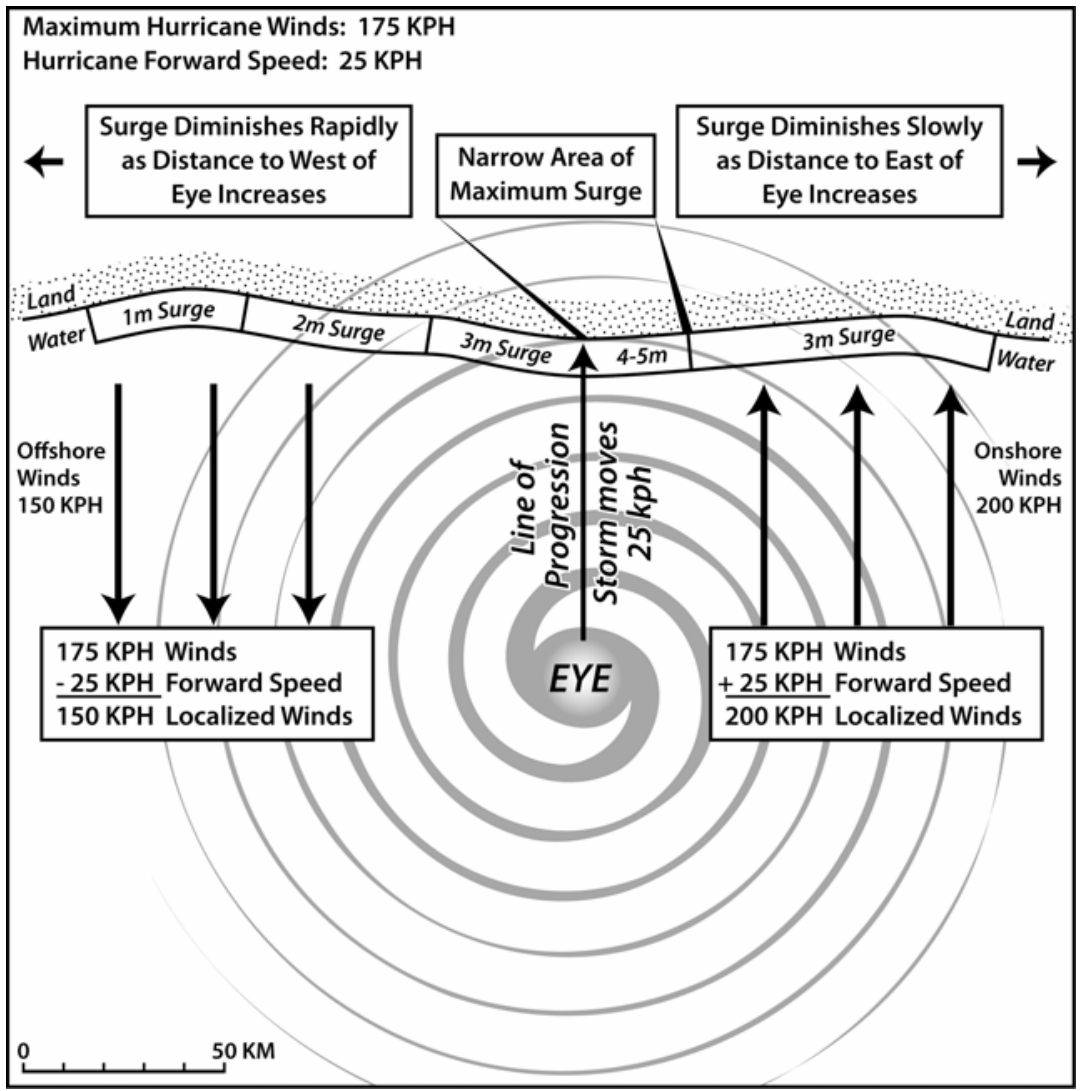

Fig. 6. Generalized schematic of storm surge heights relative to position, path and wind speeds of a tropical cyclone.

In certain cases, offshore winds create negative surges, in which winds push enough water away from land that water levels fall below normal levels. This phenomenon is usually experienced when offshore winds are observed on the leeward side of a peninsula, island or isthmus. These geographic features experience the majority of negative surges because they are wide enough to impede the surge that strikes the windward coastline, yet thin enough to not significantly weaken the cyclone. The west coast of Florida, for example, observes negative surges because cyclones commonly track from east to west across the peninsula, producing strong offshore winds to the north of the cyclonic path. Examples of this phenomenon include the negative surges of minus 2.01 meters at Tampa in October 1910 (Cline 1926), minus 1.83 meters at Tampa in September 1926 (Harris 1963) and minus 1.37 meters at Cedar Key in September 2004 (Lawrence and Cobb 2005). Sometimes positive surges immediately follow negative surges, such as the 1.07 foot positive surges that followed both the 1910 and 2004 negative surges at Tampa and Cedar Key, respectively (Cline 1926; Lawrence and Cobb 2005). Negative surges can damage property or infrastructure that are dependent upon the presence of water, such as marinas or industries that require water as a cooling agent. They can also endanger people, who are enticed by the novel opportunity to walk on the bed of a bay or 
river, unaware that a sudden change in wind direction could bury them under a torrent of rushing water. Bevan (2001), of the National Hurricane Center, reports that curious people did this very thing during Hurricane Keith (2000) in Belize.

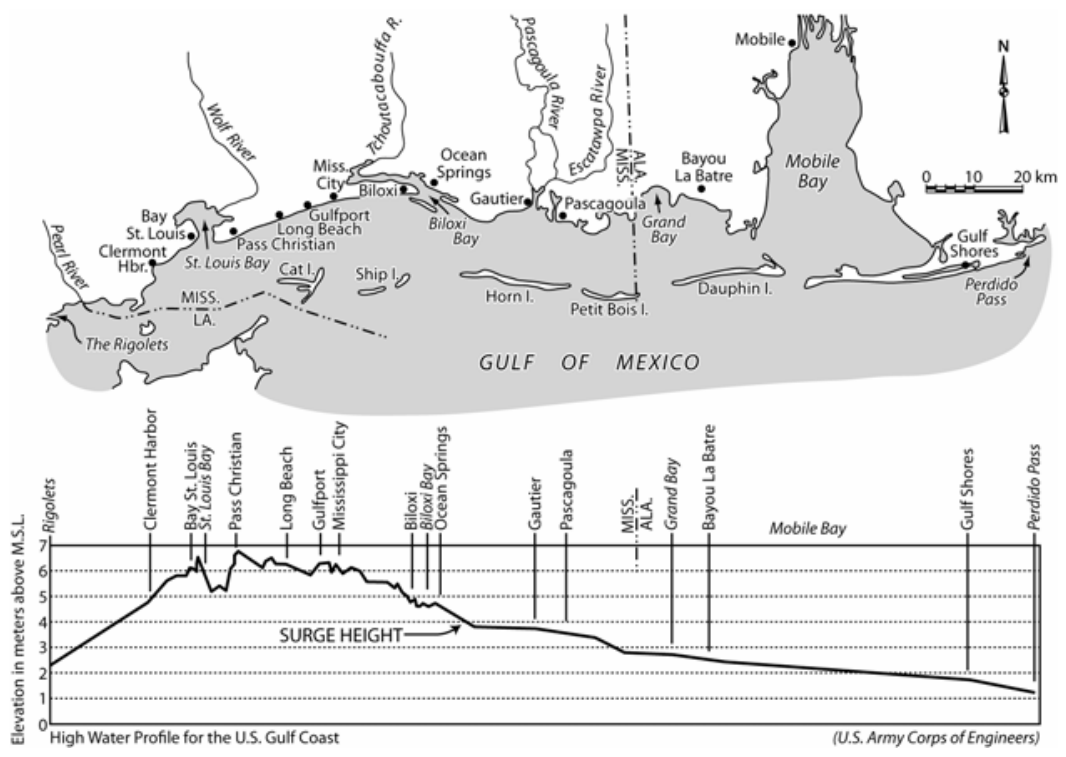

Fig. 7. High water profile for Hurricane Camille in the northern Gulf of Mexico, from U.S. Army Corps of Engineers (1970).

\section{Storm surge impact scale for coastal communities}

Scientific literature contains little information that describes the incrementally destructive nature of storm surge inundations in coastal communities as the magnitude of storm surges increase. In this regard, coastal communities lack critical information that could help them improve long-and short-term decisions in preparation for storm surge inundation. With regard to long-term decision-making, such information could improve coastal planning, thereby reducing both human and economic losses in surge events. Coastal planning would likely improve, as people understand the major, moderate and minor impacts of storm surge in their community, as well as the frequency with which those impacts are likely to occur. For example, beach erosion was a relatively minor impact of Hurricane Katrina along the Mississippi Coast, at least compared to the loss of human life and total economic losses. However, the Mississippi beaches are important for the local economy, as tourism along the Mississippi Gulf Coast generates $\$ 1.3$ billion in revenue and employs around 27,500 people (www.gulfcoast.org). Beach restoration projects have attempted to restore the sand, and return beaches to pre-Katrina conditions; an effort aimed at enhancing the quality of life in this area and boosting the local economy.

However, communities along the Mississippi Coast will likely benefit from making informed decisions on such projects, which involve knowledge of storm surge impacts and frequencies. Relevant questions may address the critical storm surge level that erodes most 
of the sand and/or how often can we expect that surge level to be repeated. As these questions are answered, local and regional governments can make informed decisions that account for localized surge risk.

With regard to short-term decision-making, such information could help in the evacuation process, as well as localized emergency preparedness. As communities understand impacts of various surge heights, they are more likely to take appropriate precautions, but less likely to over-react and take unnecessary precautions. Overreaction of local governments to storm surge threat may have negative long-term implications, as coastal populations become more skeptical of future warnings. For example, many people who evacuated the Upper Texas Coast as Hurricane Rita (2005) approached did not evacuate before Hurricane Ike (2008), because they became skeptical after Rita did not produce the anticipated surge in their specific region. Unfortunately, Ike generated a catastrophic 5.33-meter surge, which directly claimed 7 lives and was indirectly responsible for 55 other fatalities, including several people dying from carbon monoxide poisoning, a bus crash during the evacuation, and heat exhaustion. Ike also caused an estimated $\$ 10$ billion in damages (Knabb et al. 2006).

In view of this gap in the scientific literature, this chapter introduces the Storm Surge Impact Scale for Coastal Communities. This index provides information on the incremental impacts of surge inundation in coastal communities as surge levels increase, providing four categories of increasingly destructive surge impacts, listed as Impact Level 1 through Impact Level 4. These levels were defined from storm surge height and damage descriptions provided by anecdotal hurricane literature for the United States Gulf Coast. This research is based on anecdotal descriptions of over 230 surge events along the United States Gulf of Mexico from 1880-2009 which were utilized to help develop this classification system; the U.S. Government provided 15 of these quotes, newspapers provided eight, scientific journals provided five and books provided three. These quotes provide information on the surge height as well as the damage description for each surge event.

As the creation of this index was based upon anecdotal storm accounts from the U.S. Gulf Coast, specific storm surge heights associated with each increment may not apply to other water basins, although the increasingly destructive impacts of each increment would likely relate to most locations susceptible to tropical cyclone-generated storm surges. Even along the U.S. Gulf Coast, some localized differences in surge heights associated with each increment may exist, although the surge height generalizations presented in this index hold true for most communities, as this coastal area is remarkably flat, with most coastal communities residing between 1.0 and 1.5 meters above mean sea level. The lowest-impact category, Impact Level 1, describes storm surges that are less than or equal to 1.22 meters. The highest category, Impact Level 4, describes storm damage for surges of 2.44 meters or greater. Although surges on the Gulf of Mexico sometimes substantially exceed this level, the obvious visible thresholds, such as flooding of roads and coastal structures, are surpassed, making anecdotal distinctions between surges of various magnitudes in this category more difficult. Also, coastal populations should likely take similar precautions for all destructive storm surges (Impact Level 4), regardless of the storm surge magnitude within this class. It should also be noted that this index provides a valuable tool for researchers investigating physical and social history. In most locations, anecdotal accounts of extreme weather phenomena pre-date information recorded by trained scientists or instruments. Therefore, anecdotal storm descriptions are often more prevalent in historical literature than are exact measurements. This index provides a method for researchers to estimate historic storm surge heights, a practice that may be directly valuable in the fields of 
meteorology, climatology, oceanography, and geomorphology, as well as indirectly useful in fields such as engineering, health care, and history.

This new index is similar to the Storm Impact Scale for Barrier Islands, created by Sallenger, Jr. (2000), which also defines four levels of storm impacts along the coast, while focusing on the physical impacts to barrier islands, such as beach erosion and sand transport. The Storm Surge Impact Scale for Coastal Communities includes some information about beach erosion, but also includes information about impacts to coastal communities and infrastructure, such as roads and bridges.

Figure 8 displays a summarized version of this impact scale in the form of a schematic that associates surge levels with damage descriptions. The generalized patterns found in this index are subject to localized differences in topography, as well as differences in the physical landscape, such as the presence of levees, dunes or other natural or artificial floodcontrol devices.

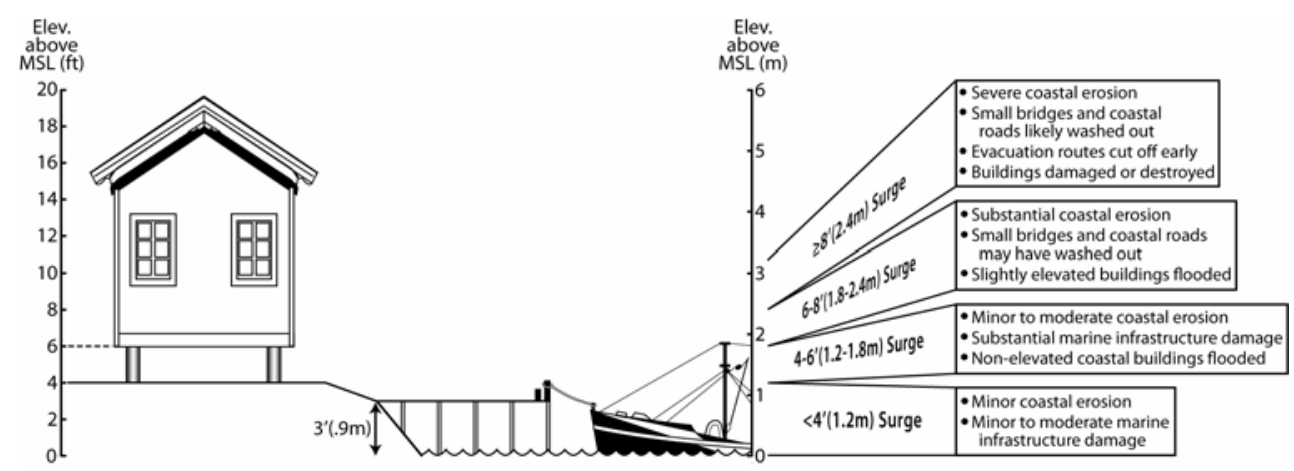

Fig. 8. Generalized schematic of storm surge impacts in communities along the U.S. Gulf coast. Marine infrastructure is estimated at .9 meters ( 3 feet), ground level of communities is estimated at 1.22 meters ( 4 feet), and slightly elevated buildings in these communities is estimated at 1.83 meters ( 6 feet) above MSL. Generalized damage descriptions associated with surge heights are listed in the right portion of diagram.

\section{Storm surge impact scale for coastal communities}

\subsection{Impact level 1: "Marine impacts"}

\section{U.S. gulf coast surge height: $<1.22$ meters $(<4$ feet)}

Damage Description: Water levels increase and are perhaps accompanied by waves, but relatively minor damage is reported. Marine infrastructure, such as docks, wharves, piers, marinas, or bath houses may sustain some damage. Non-elevated industrial equipment located outside the protection of seawalls or levees may be damaged as well. Minor beach erosion may occur. If accompanied by wave action, water may wash up against, or even over, smaller seawalls, and may reach coastal roads.

Impact Level 1 Generalization: Water is high, but mostly remains in marine areas; water does not usually reach buildings and barely crossed coastal roads if it reached them at all. See Table 2 for a list of anecdotal quotes that relate this surge height with the damage description. 


\subsection{Impact level 2: "Overwash impacts"}

\section{U.S. Gulf Coast Surge Height: $\geq 1.22$ meters and $<1.83$ meters $(\geq 4$ feet and $<6$ feet)}

Damage Description: Water washes over, and may damage coastal roads and smaller sea walls. Beach erosion occurs and is substantial if accompanied by large waves. Non-elevated structures in the coastal zone that are not protected by levees or seawalls are likely flooded. Marine infrastructure, such as docks, wharves, marinas, bath houses, as well as other structures located adjacent to the water, may sustain substantial damage or wash away, especially if accompanied by wave action.

Impact Level 2 Generalization: Water damages marine areas, crossed coastal roads and flooded non-elevated coastal buildings. See Table 3 for a list of anecdotal quotes that relate this surge height with the damage description.

\begin{tabular}{|c|c|c|c|c|}
\hline $\begin{array}{l}\text { Storm } \\
\text { Name }\end{array}$ & Year & Location & Source & Quote \\
\hline Ella & 1958 & $\begin{array}{l}\text { Florida } \\
\text { Keys }\end{array}$ & $\begin{array}{l}\text { Kurtsweil, } \\
\text { J.P., } 1958\end{array}$ & $\begin{array}{l}\text { "Tides were two feet above normal. There } \\
\text { was no flooding, but great quantities of } \\
\text { seaweed, sand and small rocks were washed } \\
\text { onto the boulevard at the southeast portion } \\
\text { of the island." }\end{array}$ \\
\hline Beulah & 1959 & Texas & $\begin{array}{l}\text { National } \\
\text { Weather } \\
\text { Bureau, } \\
1959\end{array}$ & $\begin{array}{l}\text { "Tides } 2 \text { to } 3 \text { feet above normal and rough } \\
\text { seas were reported along the lower Texas } \\
\text { coast. No reports of damage or loss of life } \\
\text { have been received." }\end{array}$ \\
\hline Judith & 1959 & Florida & $\begin{array}{l}\text { Tampa } \\
\text { Tribune, } \\
\text { October } \\
19, \quad 1959, \\
\text { Pg. } 4\end{array}$ & $\begin{array}{l}\text { "A 75-foot long section of boardwalk next } \\
\text { to Naples' city fishing pier was washed } \\
\text { away in the pounding surf - three feet } \\
\text { above normal." } \\
\text { "The Fort Myers-to-Naples stretch, south } \\
\text { of the storm's center, felt the main force of } \\
\text { the blow but there was comparatively little } \\
\text { damage." }\end{array}$ \\
\hline $\begin{array}{l}\text { Tropical } \\
\text { Storm \#1 }\end{array}$ & 1960 & Texas & $\begin{array}{l}\text { Mozeney, } \\
\text { R.P., } 1960\end{array}$ & $\begin{array}{l}\text { "One shrimp boat beached. One shrimp } \\
\text { boat and two crewmen missing. Three } \\
\text { private fishing piers wrecked at Bayside on } \\
\text { Copano Bay." }\end{array}$ \\
\hline Danielle & 1980 & Louisiana & $\begin{array}{l}\text { National } \\
\text { Hurricane } \\
\text { Center, } \\
1980\end{array}$ & $\begin{array}{l}\text { "Tides were no more than } 2 \text { to } 3 \text { feet above } \\
\text { normal on the southwest Louisiana and } \\
\text { upper Texas coasts. Beach erosion was } \\
\text { minor." }\end{array}$ \\
\hline
\end{tabular}

Table 2. Anecdotal quotes for Impact Level 1: "Marine Impacts" 


\begin{tabular}{|c|c|c|c|c|}
\hline Storm Name & Year & Location & Source & Quote \\
\hline $\begin{array}{l}\text { Great Miami } \\
\text { Hurricane }\end{array}$ & 1926 & $\begin{array}{l}\text { Florida } \\
\text { Panhandle }\end{array}$ & $\begin{array}{l}\text { Mitchell, } \\
\text { C.L., 1926, } \\
\text { Pg. } 413\end{array}$ & $\begin{array}{l}\text { "On the } 21^{\text {st }} \text { the tide was estimated at } 4.2 \text { feet } \\
\text { at } 6: 30 \text { a. m.; it was then overflowing low } \\
\text { ground along the water front with highest } \\
\text { waves running possibly } 5.0 \text { feet, portions of } \\
\text { Water Street being then from } 6 \text { to } 8 \text { inches } \\
\text { under water." } \\
\text { Note: The previous quote refers to } \\
\text { Apalachicola, Florida. }\end{array}$ \\
\hline Unnamed & 1936 & Florida & $\mid \begin{array}{l}\text { Barnes, } \\
2007, \quad \text { pgs. } \\
160-161\end{array}$ & $\begin{array}{l}\text { "Just after the storm center passed, an } \\
\text { 'abnormally high tide' occurred, which } \\
\text { measured } 5.5 \text { feet above normal and left water } \\
18 \text { inches deep in the streets of Everglades } \\
\text { City." }\end{array}$ \\
\hline Unnamed & 1941 & Florida & $\begin{array}{l}\text { Sumner, } \\
\text { H.C., 1941, } \\
\text { pg. } 303\end{array}$ & $\begin{array}{l}\text { "The lowest pressure, at Everglades City, } \\
995.6 \text { millibars (29.40 inches), was } \\
\text { accompanied by winds exceeding } 65 \text { miles per } \\
\text { hour and a tide of } 4.1 \text { feet which flooded the } \\
\text { town and surrounded low country to a depth } \\
\text { of about } 1 \text { foot." }\end{array}$ \\
\hline Baker & 1950 & $\begin{array}{l}\text { Florida } \\
\text { Panhandle }\end{array}$ & $\begin{array}{l}\text { Dothan } \\
\text { Eagle, } \\
\text { September } \\
1, \quad 1950, \text { pg. } \\
1\end{array}$ & $\begin{array}{l}\text { "Some beach property and wharves were } \\
\text { damaged when water rose five and half feet } \\
\text { above normal." }\end{array}$ \\
\hline Esther & 1957 & Mississippi & $\begin{array}{l}\text { Times- } \\
\text { Picayune, } \\
\text { September } \\
19,1957, \mathrm{pg} . \\
5\end{array}$ & $\begin{array}{l}\text { "US Highway } 90 \text { along the beach was } \\
\text { pronounced unsafe for travel by the state } \\
\text { police which sent extra troopers to detour } \\
\text { motorists as five-foot tides smashed over the } \\
\text { seawall." }\end{array}$ \\
\hline Ella & 1958 & $\begin{array}{l}\text { Texas and } \\
\text { Louisiana }\end{array}$ & $\begin{array}{l}\text { Lichtblau, } \\
\text { S., } 1958\end{array}$ & $\begin{array}{l}\text { "Highest tides were between } 2 \text { and } 4 \text { feet } \\
\text { along the Texas and Louisiana coasts. Some } \\
\text { coastal roads were closed due to tide and } \\
\text { waves." }\end{array}$ \\
\hline Candy & 1968 & Texas & $\begin{array}{ll}\text { Sugg } & \text { and } \\
\text { Hebert, } & \\
1969, & \text { pg. } \\
233 & \end{array}$ & $\begin{array}{l}\text { "Tides ranged up to } 4 \mathrm{ft} \text { in San Antonio Bay } \\
\text { and Corpus Christi Bay and were } 2 \text { to } 3 \mathrm{ft} \\
\text { elsewhere on the central and upper Texas } \\
\text { coasts. Damage was confined mainly to the } \\
\text { formation of cuts along Padre Island and } \\
\text { coastal oil industry equipment." }\end{array}$ \\
\hline Bob & 1979 & Louisiana & National & “Tides were generally 3 to 5 feet above \\
\hline
\end{tabular}




\begin{tabular}{|c|c|c|c|c|}
\hline & & & $\begin{array}{l}\text { Hurricane } \\
\text { Center, } \\
1979, \text { pg. } 1\end{array}$ & $\begin{array}{l}\text { normal and rainfall totals between } 3 \text { and } 6 \\
\text { inches...No serious flooding was reported in } \\
\text { Louisiana, Mississippi, or Alabama." } \\
\text { "A number of boats were sunk or damaged } \\
\text { and there was considerable pier damage due } \\
\text { to high tides and rough seas." }\end{array}$ \\
\hline Jeanne & 1980 & Texas & $\begin{array}{l}\text { National } \\
\text { Hurricane } \\
\text { Center, } \\
1980, \text { pg. } 2\end{array}$ & $\begin{array}{l}\text { "Tides of } 2 \text { to } 4 \text { feet above normal occurred } \\
\text { along the Texas coast accompanied by a } \\
\text { prolonged period of rough seas and heavy } \\
\text { swells. However, only minor beach erosion } \\
\text { was reported." }\end{array}$ \\
\hline Gilbert & 1988 & Texas & $\begin{array}{l}\text { National } \\
\text { Hurricane } \\
\text { Center, } \\
1988, \text { pg. } 2\end{array}$ & $\begin{array}{l}\text { "Tides of } 3 \text { to } 5 \text { feet above normal were } \\
\text { reported along the Texas coast with a number } \\
\text { of low-lying roads under water. There was } \\
\text { considerable beach erosion on Padre Island." }\end{array}$ \\
\hline \multirow[t]{2}{*}{ Alberto } & \multirow[t]{2}{*}{1994} & \multirow[t]{2}{*}{$\begin{array}{l}\text { Florida } \\
\text { Panhandle }\end{array}$} & \begin{tabular}{|l} 
Intelligencer, \\
July 4,1994, \\
pg. 41
\end{tabular} & $\begin{array}{l}\text { "A 5-mile stretch of U.S. Highway } 98 \text { from } \\
\text { Destin west to Fort Walton Beach was closed } \\
\text { for two hours because a sea wall protecting } \\
\text { the highway had eroded." }\end{array}$ \\
\hline & & & $\begin{array}{l}\text { Rappaport, } \\
\text { 1994, pg. } 3\end{array}$ & $\begin{array}{l}\text { "A storm tide of } 5 \text { feet was estimated near } \\
\text { Destin. A } 3 \text { foot storm surge (NGVD) } \\
\text { occurred at Panama City, Panama City } \\
\text { Beach, Turkey Point and Apalachicola." }\end{array}$ \\
\hline Josephine & 1996 & Louisiana & $\begin{array}{l}\text { National } \\
\text { Weather } \\
\text { Service, } \\
\text { Lake } \\
\text { Charles, LA, } \\
2009\end{array}$ & $\begin{array}{l}\text { "The highest tide noted was } 5.5 \text { feet at Bayou } \\
\text { Bienvenue, near Lake Borgne. Highway } 1 \text { was } \\
\text { under a foot of water. A few homes and roads } \\
\text { were also flooded in Orleans and St. Bernard } \\
\text { Parishes, outside the flood control levees." }\end{array}$ \\
\hline
\end{tabular}

Table 3. Anecdotal quotes for Impact Level 2: “Overwash Impacts"

\subsection{Impact level 3: "Community inundation impacts"}

U.S. Gulf Coast Surge Height: $\geq 1.83$ meters and $<2.44$ meters ( $\geq 6$ feet and $<8$ feet)

\begin{tabular}{|l|l|l|l|l|}
\hline Storm Name & Year & Location & Source & Quote \\
\hline Florence & 1953 & Florida & $\begin{array}{l}\text { The Panama City } \\
\text { News-Herald, } \\
\text { September 27, 1953, } \\
\text { pg. } 1\end{array}$ & $\begin{array}{l}\text { For a short time Port St. Joe was isolated } \\
\text { remained open. A washed-out bridge east of } \\
\text { the city interrupted travel between Port St. } \\
\text { Joe and Apalachicola while high tides on the } \\
\text { west at Hiland View, a Port St. Joe suburb, }\end{array}$ \\
\hline
\end{tabular}




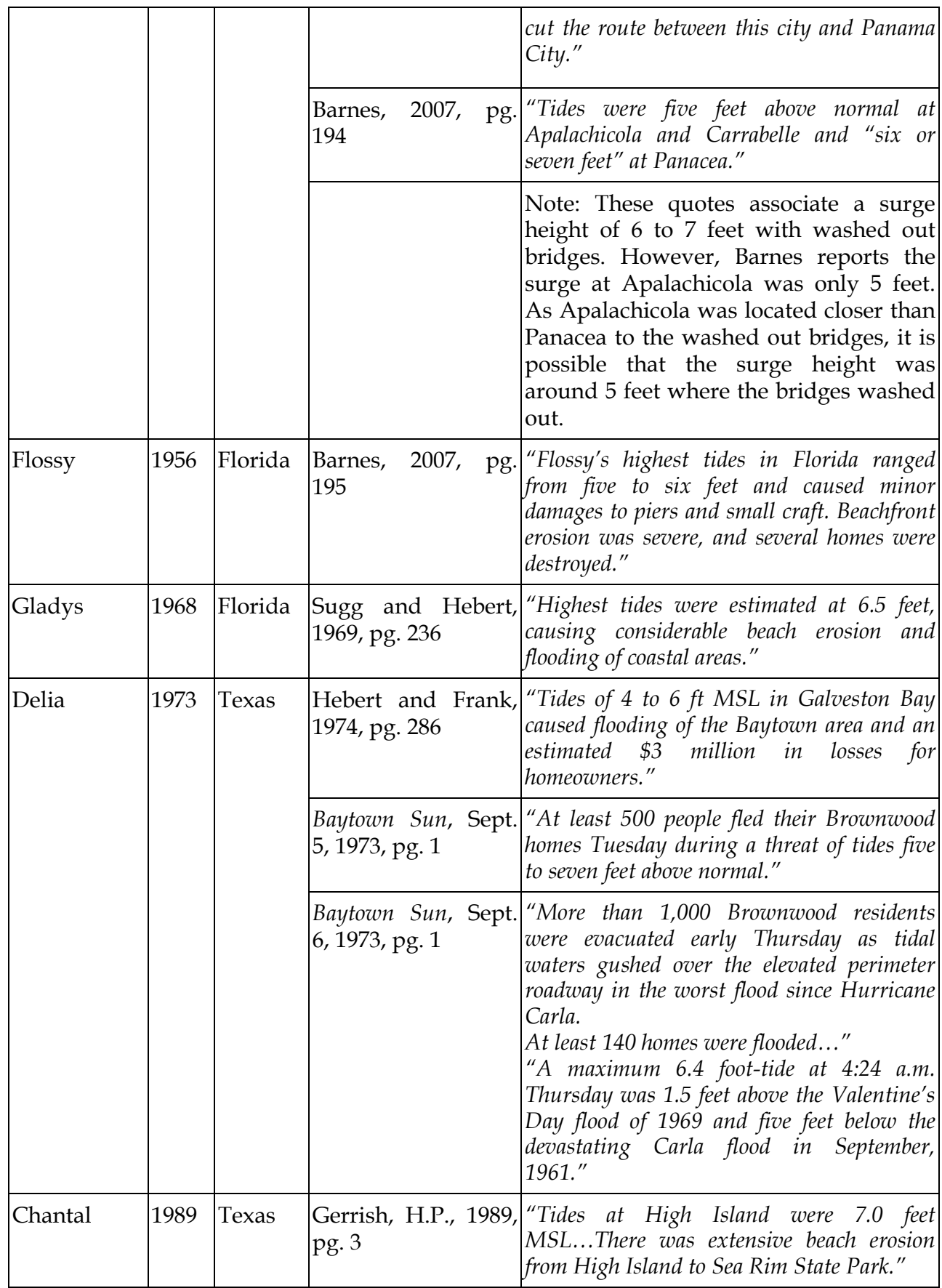

Table 4. Anecdotal quotes for Impact Level 3: "Inundation Impacts" 
Damage Description: Widespread damage or even destruction of marine infrastructure, as well as industrial infrastructure located outside flood protection levees. Coastal communities are flooded, as water enters non-elevated and slightly elevated (one meter or less) structures in the coastal zone. Coastal roads are flooded. Small bridges as well as portions of roadway may wash out. Substantial coastal erosion is observed. Storm surge impacts the coast and areas slightly inland.

Impact Level 3 Generalization: Water damages coastal buildings and infrastructure, such as roads, bridges and causeways. See Table 4 for a list of anecdotal quotes that relate this surge height with the damage description.

\subsection{Impact level 4: "Destructive impacts"}

\section{U.S. Gulf Coast Surge Height: $\geq 2.44$ meters ( $\geq 8$ feet)}

\begin{tabular}{|c|c|c|c|c|}
\hline Storm Name & Year & Location & Source & Quote \\
\hline Danny & 1985 & Louisiana & $\begin{array}{l}\text { National } \\
\text { Weather } \\
\text { Service, } \\
\text { Lake } \\
\text { Charles, } \\
\text { Louisiana, } \\
2009\end{array}$ & $\begin{array}{l}\text { "Storm surges of } 8 \text { feet were seen along the coast of } \\
\text { South Central Louisiana. Highway } 46 \text { near Hopedale in } \\
\text { St. Bernard Parish was impassable due to the high } \\
\text { waters. The pier at Grand Isle State Park was damaged, } \\
\text { while a pier near Slidell was demolished. Coastal erosion } \\
\text { was greatest in Terrebonne and Lower Jefferson } \\
\text { Parishes." }\end{array}$ \\
\hline Juan & 1985 & Louisiana & $\begin{array}{l}\text { National } \\
\text { Weather } \\
\text { Service, } \\
\text { Lake } \\
\text { Charles, } \\
\text { Louisiana, } \\
2009\end{array}$ & $\begin{array}{l}\text { "Storm surges were } 8 \text { feet at Cocodrie...LA } 1 \text { south of } \\
\text { Leeville and LA } 3090 \text { near Fourchon were destroyed. } \\
\text { Three bridges were washed out near Lacombe on LA 434. } \\
\text { Levees were overtopped in Lockport, Marrero, Oswego, } \\
\text { and Myrtle Grove; this added to the already serious } \\
\text { flooding. Two hundred cattle were drowned in } \\
\text { Terrebonne Parish. Grand Isle was under } 4 \text { feet of sea } \\
\text { water; } 1200 \text { residents were trapped on the island as the } \\
\text { storm surge cut off any evacuation attempts early on." }\end{array}$ \\
\hline \multirow[t]{2}{*}{ Allison } & \multirow[t]{2}{*}{1995} & \multirow[t]{2}{*}{ Florida } & $\begin{array}{ll}\text { Pasch, } & \text { R.J., } \\
1997 & \end{array}$ & $\begin{array}{l}\text { "Maximum storm surge heights were estimated at } 6 \text { to } 8 \\
\text { ft from Wakulla through Dixie counties..." } \\
\text { "Damage was greatest in the coastal sections of Dixie, } \\
\text { Levy, Taylor and Wakulla counties, mainly from storm } \\
\text { surge effects, with } 60 \text { houses and businesses damaged. A } \\
\text { house collapsed at Bald Point in Franklin County. About } \\
5000 \text { people evacuated from the coast. Other costal effects } \\
\text { included mostly minor beach erosion, damage to sea } \\
\text { walls and coastal roadways, and the sinking of several } \\
\text { small boats." }\end{array}$ \\
\hline & & & \begin{tabular}{|l|} 
New \\
Mexican, \\
June 6, 1995, \\
pg. 4
\end{tabular} & $\begin{array}{l}\text { "More than } 65 \text { coastal homes, three hotels and at least } \\
\text { one restaurant were flooded as the morning storm caused } \\
\text { the ocean to surge } 8 \text { feet along a 150-mile stretch of } \\
\text { Florida's Big Bend, where the Panhandle meets the } \\
\text { Peninsula." }\end{array}$ \\
\hline Josephine & 1996 & Florida & $\begin{array}{ll}\text { Pasch, } & \text { R.J., } \\
1997 & \end{array}$ & $\begin{array}{l}\text { "County officials estimated storm tides (storm surge } \\
\text { plus astronomical tide) ranged from up to } 9 \text { feet in Levy } \\
\text { County...These tides produced widespread flooding of } \\
\text { roads, dwellings, and businesses." }\end{array}$ \\
\hline
\end{tabular}

Table 5. Anecdotal quotes for Impact Level 4: "Destructive Impacts" 
Damage Description: Severe coastal erosion is observed. Severe damage is inflicted on marine infrastructure, as well as any industrial equipment, residential or commercial structures located outside flood protection levees. Structures in coastal zone, even if elevated or protected by levees, may be damaged or completely destroyed. Small bridges and coastal roads are likely washed out. Evacuation routes are cut off hours before the peak surge level arrives. Water may overtop levees. Surge likely penetrates inland.

Impact Level 4 Generalization: Water greatly damages coastal structures, washing some away, or creating complete loss. Water also penetrates inland. See Table 5 for a list of anecdotal quotes that relate this surge height with the damage description.

\section{Summary and conclusion}

Several physical processes are responsible for generating storm surges in association with landfalling tropical storms and hurricanes. Although wind stress is the predominant factor forcing surge heights, several other processes often enhance or diminish maximum surge heights. Low air pressure clearly contributes to storm surge, but its overall impact is modest. Cyclonic size is an important factor that has been underestimated until recently, after very large hurricanes Katrina (2005) and Ike (2008) generated larger surges than anticipated. Forward cyclonic movement is another factor which influences surge heights, as slower moving storms often produce higher surges, and inundate the coastline for longer periods of time. Coastline shape and the presence of natural and artificial obstructions to flowing water, such as coastal forests and levees, sometimes have profound localized effects on storm surge height, especially where water approaches the coast or a barrier in a perpendicular direction, and is forced to rise. Shallow bathymetry is another factor which enhances surge heights, as underwater currents cannot distribute water unless the bathymetry is relatively deep.

After recognizing these contributing factors leading up to storm surge, it should come as no surprise that Hurricane Category alone cannot accurately estimate surge at a specific coastline. As a result, this chapter also presented a classification system for surge based on anecdotal information mostly from U.S. government sources, newspapers and books. The classification system has four categories of increasingly destructive surge impacts, ranging from Impact Level 1, with minor "Marine Impacts" to Impact Level 4, with "Destructive Impacts" that often penetrate far inland. The classification should be of some benefit to coastal zone planners, emergency managers, and researchers.

\section{References}

Ali, A., 1996: Vulnerability of Bangladesh to climate change and sea level rise through tropical cyclones and storm surges. Water, Air, and Soil Pollution, 92, 171-179.

Barnes, J., 2007: Florida's Hurricane History. 2nd edition. University of North Carolina Press, 407 pp.

Baytown Sun, Baytown, Texas, Wednesday, September 5, 1973, Page 1. Author unknown.

Baytown Sun, Baytown, Texas, Thursday, September 6, 1973, Page 1. Author unknown.

Berg, R., 2009: National Hurricane Center Tropical Cyclone Report on Hurricane Ike (AL092008), updated January 23, 2009. Published on the Web at http://www.nhc.noaa.gov/pdf/TCR-AL092008_Ike.pdf. 
Bevan, J., 2001: National Hurricane Center Tropical Cyclone Report on Hurricane Keith, updated January 29, 2001. Published on the Web at http://www.nhc.noaa.gov/2000keith.html.

Chen, Q., L. Wang, R. Tawes, 2008: Hydrodynamic response of northeastern Gulf of Mexico to hurricanes. Estuaries and Coasts, 31, 1098-1116.

Cline, I, 1926: Tropical Cyclones. Macmillon Company, 301 pp.

De, U.S., R.K. Dube, G.S. Prakasa Rao, 2005: Extreme weather events over India in the last 100 years. Journal of Indian Geophysical Union, 9, 173-187.

De Scally, F.A., 2008: Historical tropical cyclone activity and impacts in the Cook Islands. Pacific Science, 62, 443-459.

Dothan Eagle, Dothan, Alabama, Friday afternoon, September 1, 1950. Author unknown.

Dube, S.K., A.D. Rao, P.C. Sinha, T.S. Murty, N. Bahulayan, 1997: Storm surge in the Bay of Bengal and Arabian Sea: The problem and its prediction. Mausam, 48, 283304.

Ebersole, B.A., J.J. Westerlink, S. Bunya, J.C. Dietrich, and M.A. Cialone, 2010: Development of storm surge which led to flooding in St. Bernard Polder during Hurricane Katrina. Ocean Engineering, 37, 91-103.

Frank, N.L., and S.A. Husain, 1971: Deadliest tropical cyclone in history. Bulletin of the American Meteorological Society, 52, 438-\&.

Garriott, E.B., 1900: West Indian hurricane of September 1-12, 1900. Monthly Weather Review, 28, 371-378.

Gerrish, H.P., 1989: Preliminary Report, Hurricane Chantal, 30 July to 3 August 1989. Report published at the National Hurricane Center, Miami, Florida. Available on the Web at: $\quad$ http://www.nhc.noaa.gov/archive/storm_wallets/atlantic/atl1989prelim/chantal/prelim03.gif.

Gray, W.M., 1975: Tropical cyclone genesis. Atmospheric science paper No. 234, Department of Atmospheric Science, Colorado State University, Fort Collins, CO.

Gray, W.M., 1975: Global view of tropical cyclone genesis. Bulletin of the American Meteorological Society, 56, 322.

Gray, W. M., 1998: The formation of tropical cyclones. Meteorology and Atmospheric Physics, 67, 37-69.

Harris, L.D., 1963: Characteristics of the Hurricane Storm Surge. U.S. Weather Bureau, Technical Paper No. 48.

Hebert, P.J. and N.L. Frank, 1974: Atlantic Hurricane Season of 1973. Monthly Weather Review, 102, 280-289.

Holland, G.J., 1997: The maximum potential intensity of tropical cyclones. Journal of the Atmospheric Sciences, 54, 2519-2541.

Intelligencer, Doylestown, Pennsylvania, Monday, July 4, 1994, Page 41.

Interagency Performance Evaluation Taskforce Report (IPET), 2006: Performance Evaluation of the New Orleans and Southeast Louisiana Hurricane Protection System, Draft Final Report of the Interagency Performance Evaluation Task Force. U.S. Army Corps of Engineers, Volume 1- Executive Summary and Overview, June 1, 2006.

Irish, J.L., D.T. Resio, J.J. Ratcliff, 2008: The influence of storm size on hurricane surge. Journal of Physical Oceanography, 38, 2003-2013. 
Irish, J.L., D.T. Resio, and M.A. Cialone, 2009: A surge response function approach to coastal hazard assessment. Part 2: Quantification of spatial attributes response functions. Natural Hazards, 51, 183-205.

Jarvinen, B.J., and C.J. Neumann, 1985: An evaluation of the SLOSH storm surge model. Bulletin of the American Meteorological Society, 66, 1408-1411.

Jordan II, M.R. 2008: Development of a new storm surge index for global prediction of tropical cyclone generated storm surge. Dissertation, Florida State University, Tallahassee, FL, 82 pp.

Jordan II, M.R., and C.A. Clayson, 2008: Evaluating the usefulness of a new set of hurricane classification indices. Monthly Weather Review, 136, 5234-5238.

Jordan II, M.R., and C.A. Clayson, 2008: A new approach to using wind speed for prediction of tropical cyclone generated storm surge. Geophysical Research Letters, 35, article number: L13802.

Keim, B., R. Muller, G. Stone, 2007: Spatiotemporal Patterns and Return Periods of Tropical Storm and Hurricane Strikes from Texas to Maine. Journal of Climate, 20, 3498-3509.

Keim, B.D., and R.A. Muller, 2008: Overview of Atlantic Basin Hurricanes. Chapter 4, pp. 79-89, in: Walsh, P.J., S.L. Smith, L.E. Fleming, H.M. Solo-Gabrielle, W.H. Gerwick, Oceans and Human Health. Academic Press, Burlington, Massachusetts, 644 pp.

Keim, B.D., and R.A. Muller, 2009: Hurricanes of the Gulf of Mexico. Louisiana State University Press, 216 pp.

Knabb, R.D., J.R. Rhome, D.P. Brown, 2006: National Hurricane Center Tropical Cyclone Report on Hurricane Katrina. Published on the Web at: http://www.nhc.noaa.gov/pdf/TCR-AL122005_Katrina.pdf.

Knabb, R.D., D.P. Brown, J.R. Rhome, 2006: National Hurricane Center Tropical Cyclone Report on Hurricane Rita. Published on the Web at: http://www.nhc.noaa.gov/pdf/TCR-AL182005_Rita.pdf.

Kurian, N.P., N. Nirupama, M. Baba, K.V. Thomas, 2009: Coastal flooding due to synoptic scale, meso-scale and remote forcings. Natural Hazards, 48, 259-273.

Kurtsweil, J.P., 1958: Narrative Report of Hurricane Ella. Report published as U.S. Weather Bureau Office Memorandum, Key West, Florida. Available on the Web at: http://www.nhc.noaa.gov/archive/storm_wallets/atlantic/atl1958/ella/preloc/p sheyw.gif.

Landsea, C., 2007: Record number of storms by basin. Table published on the Web through the Atlantic Oceanographic and Meteorological Laboratory, Hurricane Research Division at: http://www.aoml.noaa.gov/hrd/tcfaq/E10.html.

Lawrence, M, and H. Cobb, 2005: National Hurricane Center Tropical Cyclone Report on Hurricane Jeanne, updated January 7, 2005. Published on the Web at http://www.nhc.noaa.gov/pdf/TCR-AL112004_Jeanne.pdf.

Lichtblau, S., 1958: Report on Tropical Storm Ella Sept. 3 to 6, 1958, in the Gulf of Mexico. Report published by the National Weather Bureau. Available on the Web at: http://www.nhc.noaa.gov/archive/storm_wallets/atlantic/atl1958/ella/preloc/p shnew.gif. 
McTaggart-Cowan R., G.D. Deane, L.F. Bosart, C.A. Davis, T.J. Galarneau, Jr., 2008: Climatology of tropical cyclogenesis in the North Atlantic (1948-2004). Monthly Weather Review, 136, 1284-1304.

Mitchell, C.L., 1926: The West Indian Hurricane of September 14-22, 1926. Monthly Weather Review, 54 (10). Available on the Web at: http://www.aoml.noaa.gov/general/lib/lib1/nhclib/mwreviews/1926.pdf.

Mozeney, R.P., 1960: Tropical Low Report for June 23-24. Report published by the National Weather Bureau. Available on the Web at:

http://www.nhc.noaa.gov/archive/storm_wallets/atlantic/atl1960/td1/preloc /pshcrp.gif.

National Aeronautics and Space Administration, 2010: NASA Quest- an Educational Web Site. Available on the Web at: http://quest.nasa.gov/aero/planetary/mars.html

National Hurricane Center, Miami, Florida, 1979: Preliminary Report, Hurricane Bob, 9-16 July, 1979. Author only identified by initials, "GBC." Available on the Web at: http://www.nhc.noaa.gov/archive/storm_wallets/atlantic/at11979prelim/bob/prelim01.gif.

National Hurricane Center, Miami, Florida, 1980: Report on Tropical Storm Danielle, 4-7 September 1980. Author unknown. Available on the Web at: http://www.nhc.noaa.gov/archive/storm_wallets/atlantic/at11980prelim/danielle/prelim02.gif.

National Hurricane Center, Miami, Florida, 1980: Preliminary Report, Hurricane Jeanne, November 7-16, 1980. Author only identified by initials "JMP." Available on the Web at: http://www.nhc.noaa.gov/archive/storm_wallets/atlantic/atl1980prelim/jeanne/prelim02.gif.

National Hurricane Center, Miami, Florida, 1988: Preliminary Report, Hurricane Gilbert, 0819 September 1988. Author only identified by initials, "GBC." Available on the Web at: $\quad$ http://www.nhc.noaa.gov/archive/storm_wallets/atlantic/atl1988prelim/gilbert/prelim02.gif.

National Oceanic and Atmospheric Administration, 1999: NOAA's Top U.S. Weather, Water and Climate Events of the 20 $0^{\text {th }}$ Century. Available on the Web at: http://www.noaanews.noaa.gov/stories/s334c.htm

National Weather Bureau, 1959: Preliminary report on Tropical Storm Beulah, June 15-18, 1959. Author unknown. Available on the Web at: http://www.nhc.noaa.gov/archive/storm_wallets/atlantic/at11959/beulah/ prenhc/prelim1.gif.

National Weather Bureau, September 1969: Preliminary Report on Hurricane Camille. Author unknown, document published on the Web at: http://www.nhc.noaa.gov/archive/storm_wallets/atlantic/atl1969prelim/camille/TCR-1969Camille.pdf.

National Weather Service, Lake Charles, Louisiana, 2009: Louisiana Hurricane History. Author unknown. Available on the Web at: http:/ / www.srh.noaa.gov/lch/research/lalate20hur2.php. 
National Weather Service, Lake Charles, LA, 2009: Louisiana Hurricane History. Author unknown. Available on the Web at:

http://www.srh.noaa.gov/lch/research/lalate20hur3.php.

Neumann, C.J., B.R. Jarvinen, C.J. McAdie, J.D. Elms, 1993: Tropical cyclones of the North Atlantic Ocean. U.S. Department of Commerce, prepared by the National Climate Data Center, Asheville, North Carolina, 193 pp.

New Mexican, Santa Fe, New Mexico, Tuesday, June 6, 1995. Author unknown.

Panama City News-Herald, Panama City, Florida, September 27, 1953. Author unknown.

Pasch, R.J., 1996: Preliminary Report, Hurricane Allison, 3-6 June 1995. Report published at the National Hurricane Center, Miami, Florida. Available on the Web at: http://www.nhc.noaa.gov/1995allison.html.

Pasch, R.J., Florida, 1997: Preliminary Report, Tropical Storm Josephine, 4-8 October 1996. Report published at the National Hurricane Center, Miami, Florida. Available on the Web at: http:/ / www.nhc.noaa.gov/1996josephin.html.

Pasch, R.J., D.P. Brown, and E.S. Blake, 2004: Tropical Cyclone Report, Hurricane Charley, 914 August 2004. Available on the Web at:

http://www.nhc.noaa.gov/pdf/TCR-AL032004_Charley.pdf.

Rappaport, E.N., 1994: Preliminary Report, Tropical Storm Alberto, 30 June - 7 July 1994. Report published at the National Hurricane Center, Miami, Florida. Available on the Web at:

http://www.nhc.noaa.gov/archive/storm_wallets/atlantic/atl1994/alberto/ prenhc/prelim03.gif.

Rappaport, E.N, and J.J. Fernandez-Partagas, 1995: The deadliest Atlantic tropical cyclones, 1492-1994. NOAA Technical Memorandum NWS NHC-47, National Hurricane Center, $41 \mathrm{pp}$.

Rego, J.L., and C. Li, 2009: On the importance of the forward speed of hurricanes in storm surge forecasting: A numerical study. Geophysical Research Letters, 36, L07609.

Sallenger, Jr., A.H., 2000: Storm Impact Scale for Barrier Islands. Journal of Coastal Research, $16,890-895$.

Simpson, R.H., A. L. Sugg, and Staff, 1970: The Atlantic Hurricane Season of 1969. Monthly Weather Review, 98, 293-306.

Sugg, A.L. and P.J. Hebert, 1969: The Atlantic Hurricane Season of 1968. Monthly Weather Review, 97 (3), pp. 225-255.

Sumner, H.C., 1941: Hurricane of October 3-12 and Tropical Disturbance of October 18-21, 1941. Monthly Weather Review, October 1941. Available on the Web at: http://www.aoml.noaa.gov/general/lib/lib1/nhclib/mwreviews/1941.pdf.

Tampa Tribune, Tampa, Florida, October 19, 1959. Author unknown.

Times-Picayune, New Orleans, Louisiana, September 19, 1957. Author unknown.

United States Army Corps of Engineers, 1970: Hurricane Camille, 14-22 August 1969. Mobile, Alabama.

Welander, Pierre, 1961: Numerical Prediction of Storm Surges, in Advances in Geophysics, 8. Edited by H.E. Landsberg and J. van Mieghem. Published by Academic Press, Inc., New York, USA, 316 pp.

Weisberg, R.H., and L. Zheng, 2006: Hurricane Storm Surge Simulations for Tampa Bay. Estuaries and Coasts, 29, 899-913. 


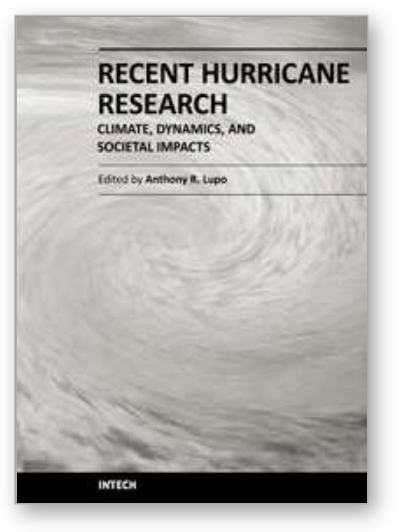

\author{
Recent Hurricane Research - Climate, Dynamics, and Societal \\ Impacts \\ Edited by Prof. Anthony Lupo
}

ISBN 978-953-307-238-8

Hard cover, 616 pages

Publisher InTech

Published online 19, April, 2011

Published in print edition April, 2011

This book represents recent research on tropical cyclones and their impact, and a wide range of topics are covered. An updated global climatology is presented, including the global occurrence of tropical cyclones and the terrestrial factors that may contribute to the variability and long-term trends in their occurrence. Research also examines long term trends in tropical cyclone occurrences and intensity as related to solar activity, while other research discusses the impact climate change may have on these storms. The dynamics and structure of tropical cyclones are studied, with traditional diagnostics employed to examine these as well as more modern approaches in examining their thermodynamics. The book aptly demonstrates how new research into short-range forecasting of tropical cyclone tracks and intensities using satellite information has led to significant improvements. In looking at societal and ecological risks, and damage assessment, authors investigate the use of technology for anticipating, and later evaluating, the amount of damage that is done to human society, watersheds, and forests by land-falling storms. The economic and ecological vulnerability of coastal regions are also studied and are supported by case studies which examine the potential hazards related to the evacuation of populated areas, including medical facilities. These studies provide decision makers with a potential basis for developing improved evacuation techniques.

\title{
How to reference
}

In order to correctly reference this scholarly work, feel free to copy and paste the following:

Hal Needham and Barry D. Keim (2011). Storm Surge: Physical Processes and an Impact Scale, Recent Hurricane Research - Climate, Dynamics, and Societal Impacts, Prof. Anthony Lupo (Ed.), ISBN: 978-953-307238-8, InTech, Available from: http://www.intechopen.com/books/recent-hurricane-research-climate-dynamicsand-societal-impacts/storm-surge-physical-processes-and-an-impact-scale

\section{INTECH}

open science | open minds

\author{
InTech Europe \\ University Campus STeP Ri \\ Slavka Krautzeka 83/A \\ 51000 Rijeka, Croatia \\ Phone: +385 (51) 770447 \\ Fax: +385 (51) 686166 \\ www.intechopen.com
}

\author{
InTech China \\ Unit 405, Office Block, Hotel Equatorial Shanghai \\ No.65, Yan An Road (West), Shanghai, 200040, China \\ 中国上海市延安西路65号上海国际贵都大饭店办公楼 405 单元 \\ Phone: +86-21-62489820 \\ Fax: +86-21-62489821
}


(C) 2011 The Author(s). Licensee IntechOpen. This chapter is distributed under the terms of the Creative Commons Attribution-NonCommercialShareAlike-3.0 License, which permits use, distribution and reproduction for non-commercial purposes, provided the original is properly cited and derivative works building on this content are distributed under the same license. 